\title{
Optimize the Role of Commitment of Employees in Improving Accountability Office Report on Local Government Budget
}

\author{
Siti Istikhoroh ${ }^{1} \&$ Yuni Sukamdani ${ }^{2}$ \\ ${ }^{1,2}$ Accounting Studies Program, University of PGRI Adi Buana Surabaya, Indonesia \\ Correspondence: Priyono, Graduate Program Master of Management, Universitas Bina Darma, Palembang, \\ Indonesia. Tel: 62-812-1697-4878. E-mail: priyono.unu_sidoarjo@yahoo.com
}

Received: September 20, 2017

Accepted: October 11, 2017

Online Published: October 15, 2017

doi:10.5539/ijef.v9n12p116

URL: https://doi.org/10.5539/ijef.v9n12p116

\begin{abstract}
This study aims to analyze the factors that affect employee commitment so that its role in improving the accountability of budget reporting can be optimized. The study was conducted on 20 units of East Java Provincial Government Office in 2016. Data were collected by giving questionnaires to 268 respondents and analyzed using multiple linear regression method. Researchers establish organizational learning and locus of control as a variable that affects the commitment of employees. The results of the analysis prove that employee commitment can be optimized through organizational learning process with indicators in the form of thinking systems, mentality, personal skills, teamwork, and understanding of the vision of the organization. Meanwhile, locus of control measured by internal control and external control proved unable to increase employee commitment.
\end{abstract}

Keywords: participative bugdeting, commitment employees, organizational learning, locus of control

\section{Introduction}

Budget is an important component in an organization, whether o rganisasi profit or non-profit, private and public organizations. Budgeting should be done precisely, using appropriate models, as well as an adequate cost calculation. There are fundamental differences between the budgets of the private sector with the public sector budget/government. Private sector budgets are generally confidential because the source of funds used is own capital, while public sector budgets should be announced to the public as the source of funds used is the property of the community. Included in the budget resources of the public sector, among others taxes, levies, SOE profits, loans and government bonds, etc.

The process of budgeting can be done through several approaches that are top down (authoritative) and bottom up (participatory). Sardjito (2005) stated that in the top down budgeting system, the plan and the budget amount has been determined by the superiors/holders of the budget while the subordinates / budget implementers only do what has been established. Typically, the application of this system makes the performance of subordinates is not effective because employers often demand high performance while the resources are ya ng is too small (limited). Meanwhile, the bottom up budgeting system (participative budgeting) is budgeting approach that focuses on efforts to improve the motivation for the employees in the organization. Subordinates or budget executors involved in the preparation of budgets that relate to sub-sections so that an agreement is reached between the boss or the holder of the power of the budget with subordinates / executors of the budget. Such model budgeting serves as a performance appraisal tool based on target achievement and efficient use of the budget. Achieving budget targets indicates good performance, and vice versa.

Research is a continuation of previous research process which has concluded that participative budgeting has an effect on managerial performance of East Java Province. Organizational commitment proved able to moderate the influence, while the perception of innovation is not able to moderate. Following up the results of such research, it is necessary further research to analyze the factors that can increase organizational commitment and strategy to improve the perception of innovation for all employees. In this case, the process of organizational learning and locus of control each employee is predicted as a variable that can affect organizational commitment. Systems thinking, mentality, personal skills, teamwork, and understanding of the organization's vision is an indicator measuring organizational learning, while the power of the individual to resist outside influences measured through self-control internally and externally. 
Budget execution involves all human resources in the organization so that its accountability becomes the responsibility of each technical user of the budget user of the organization. Accountability for performance is dependent on the duties and responsibilities of each employee, but the performance accountability of government employees by Mardiasmo (2002) can be measured from the determination of strategic planning, implementation program, reporting up to performance evaluation. Based on this phenomenon, this study uses the results of first year research analysis and analysis of questionnaires spread in the second year as a complementary material that will be required in preparing the budgeting reporting model in order to realize performance accountability.

As a public organization, the Provincial Office of East Java Province is required to maintain its credibility in the community through the achievement of performance programs that favor public interest. Organizational credibility is a value that is formed from performance accountability so that its realization requires human resources who are able to perform their duties professionally, have a high commitment to advance the organization, have high self-control and able to report accountable budget usage. Mowen and Hansen (2004) say that the participative budgeting system is able to describe the type of work program of the organization and measure the level of program achievement because it contains the functions of planning and supervision. If planning is the foresight to determine what actions should be performed, then control is the view to the rear to see if anything has been done in accordance with the plan.

This study has both theoretical and practical benefits. At the theoretical level the research results can be used as a reference in formulating the theory of leadership and employee performance improvement in public organizations. While at practical level, this research can be used as input to local government about:

a. The need to create an open budget that is able to explain where the income is gained and what the funds are spent on.

b. The importance of making the program work systematically to realize the goals of the organization gradually in accordance with the budget schedule.

c. Strategy to create a credible government apparatus, capable of performing tasks professionally in accordance with the standards of knowledge owned and trusted by the public for being able to report the accountable use of budgets.

\section{Literature Review}

\subsection{Participatory Budgeting}

A budget is a statement of the estimated performance that an organization is trying to achieve over a period of time specified in financial size (Mardiasmo, 2002). Benefits of the budget, among others: 1) tools for managers to do the planning, 2) provide information that can be used to improve decision making, 3) provide performance evaluation standards, and 4) improve communication and coordination.

The budgeting process is an important activity because the budget has the possibility of functional and dysfunctional impact on the attitudes and behavior of members of the organization. The impact is indicated by the presence or absence of budget functions as a good control tool to motivate the members of the organization to improve its performance. Sardjito (2005) stated that the budget can be done through:

1) Top down or budgeting authoritative

In the top-down budgeting, top management determine the entire budget period, as well as compile the entire operating budget (including lower level operations). Authoritative budgets are not communicating but giving orders. However, this budgeting can provide better decision-making control than participatory budgeting.

\section{2) Bottom up or budgeting participatory}

Participatory budgeting is a good communication tool as it allows top management to understand the problems faced by employees. This method can increase employee motivation to achieve organizational goals. However, if not properly controlled, participative budgets can lead to budget targets that are easily achieved or not in accordance with the target company.

\subsection{Organizational Commitment}

Organizational commitment is defined as the degree to which an employee is favoring an organization and desires to retain membership in the organization (Robins, 2003). Organizational commitment is a positive dimension of the attitude of the employees related to the performance as an indicator measuring the level of feelings and confidence in the organization where they work (Setyanto. Arif Budi, 2011). In the commitment there is a genuine effort and attachment of individuals to achieve targets, prioritize the interests of the organization, and try to make 
the organization more productive and profitable.

Organizational commitment woke up when people develop three attitudes: 1) Identification, an understanding or appreciation of the purpose organization, 2) involment, a feeling of being involved in an occupation or a feeling that his job is fun, 3) Loyalty, a sense that the organization is a work and residence comfortable. Organizational commitment has three dimensions, namely, 1) Affective (affective comitment) if an employee wants to be part of the organization because of their emotional attachment or sense of belonging, 2) Sustainable (continuance comitment), if employees stay in an organization because he needed the salary and other benefits, and 3) Normative (normative comitment), if the employee persisted in organization for moral or ethical reasons. Someone said to have committed a great organization if all three dimensions of commitment are developed jointly.

\subsection{Budget Accountability Reporting}

Accountability of budget reporting can not be separated from employee performance accountability system. The performance accountability system of government agencies is an order, instrument, and method of accountability including: 1) strategic planning, 2) performance measurement, 3) performance reporting, and 4) information utilization for continuous improvement of performance. Head of the State Administration Institution said that the performance accountability of government agencies can be built through the following principles:

- There is a commitment from the leadership and all staff to make measurable and reliable performance reporting. Honest, objective, transparent, and accurate reporting.

- Running a system that guarantees consistent use of resources in accordance with applicable laws and regulations

- Shows the level of achievement of goals and objectives that have been set

- Oriented to the vision and mission, as well as achieving the results and benefits that have been obtained by the organization at each period.

- Presents the success or failure in achieving the goals that have been set.

Stoner et al. (1995) argues that the internal and external locos of control measures how much a person is able to control events that affect them and therefore contributes to accountability for performance.

\subsection{Organizational Learning}

Organizational learning is a process to provide an understanding of the company's vision and mission to all employees. Marquardt (1996) stated that individual learning and organizational learning are inseparable. Learning organization through individuals who are part of the organization. Individual learning refers to the change of expertise, insight, knowledge, attitudes, and values obtained by a person through experience, insights and observations.

Mills and Friesen (1992) describe the key characteristics of organizational learning: first, the organization must be committed to knowledge. That is, the organization has a commitment to continuously seek to gain knowledge. Second, organizational learning must have a mechanism of renewal (a mechanism of renewal) within the organization. Departments and other units within the organization are slowly getting into the bureaucracy. Third, organizational learning must have openness to the outside world. This involves a variety of ways, because so many things the organization must learn from its environment. Various things concerning openness such as managers require knowledge of how the business environment changes periodically and the willingness to continue to follow formal education. The marketing department should be responsive to the changing tastes of consumers and suppliers. All are examples of openness to the outside world.

In social learning, Rotter (1966) said that basically each individual receives a different defense power in some conditions. Locus of control is the belief that the individual is able to control events that affect them. Invancev ich and Matterson (1991) say that locus of control has two dimensions, namely:

1) Internal l ocus of control. A person with an internal locus of control are more active height information from the outside because they are convinced of his ability to control external influences.

2) External locus of control. Someone with an external locus of control high believing that what happened to him affected by anything that happens in the environment.

Compared with an external locus of control, one oriented to the internal locus of control is more able to deal with stressful situations, more open, more honest, and more innovative in developing the organization. 


\section{Research Methods}

\subsection{Population and Sample}

The study population was all employees of the Department of East Java Province amounted to 11.598 people scattered in 20 offices. Sample set based on random quota sampling using the formula Slovin with epsilon level of $10 \%$ and given in an exidental manner. The number of questionnaires that could be analyzed as many as 268 pieces.

\subsection{Research Variable}

Variables this study consists of:

1) Employee Commitment

Encouragement from within individuals to do something in order to support organizational success
a. Ability to work above average
b. Pride is part of the organization
c. Willingness to do all the work
d. The suitability of individual values with the value of the organization
e. Satisfaction choosing organization as work place
f. Concern for the future of the organization
2) Organizational Learning

Is a process undertaken by the organization to provide understanding of the vision / mission and organizational goals to all employees
a. Thinking System
b. Mentality
c. Personal Skills
d. Teamwork
e. Shared Vision

3) Locus of Control

The power of the individual to survive from outside influences
a. Internal locus of control
b. External locus of control

4) Accountability Reporting

Order, instruments, and methods of accountability budget can be accounted for truth
a. Determination of strategic planning / strategic plan
b. Performance measurement
c. Performance reporting
d. Utilization of information for continuous improvement of performance.

\subsection{Data Analysis and Discussion}

\subsubsection{Data Presentation}

This study is a survey research and questionnaire as a research instrument. Recapitulation of the results of questionnaires is presented in Table 1. 
Table 1. Summary of questionnaire completion results

\begin{tabular}{|c|c|c|c|c|c|c|c|c|c|c|c|}
\hline \begin{tabular}{|l} 
No. \\
\end{tabular} & $\mathrm{PO}$ & LO & $\mathrm{AP}$ & No. & $\mathrm{PO}$ & LO & $\mathrm{AP}$ & No. & $\mathrm{PO}$ & $\mathrm{LO}$ & $\mathrm{AP}$ \\
\hline 1 & 50 & 44 & 48 & 91 & 44 & 44 & 42 & 181 & 42 & 42 & 38 \\
\hline 2 & 46 & 42 & 44 & 92 & 38 & 44 & 38 & 182 & 39 & 34 & 36 \\
\hline 3 & 50 & 50 & 48 & 93 & 47 & 50 & 36 & 183 & 46 & 42 & 45 \\
\hline 4 & 44 & 48 & 44 & 94 & 38 & 50 & 35 & 184 & 50 & 50 & 46 \\
\hline 5 & 35 & 50 & 38 & 95 & 40 & 42 & 46 & 185 & 44 & 34 & 50 \\
\hline 6 & 47 & 50 & 48 & 96 & 50 & 50 & 50 & 186 & 35 & 38 & 42 \\
\hline 7 & 38 & 45 & 42 & 97 & 42 & 48 & 42 & 187 & 47 & 45 & 42 \\
\hline 8 & 40 & 34 & 44 & 98 & 40 & 50 & 42 & 188 & 46 & 44 & 50 \\
\hline 9 & 50 & 42 & 46 & 99 & 50 & 44 & 50 & 189 & 40 & 48 & 50 \\
\hline 10 & 50 & 50 & 50 & 100 & 42 & 48 & 50 & 190 & 42 & 50 & 38 \\
\hline 11 & 50 & 34 & 42 & 101 & 50 & 50 & 46 & 191 & 42 & 50 & 48 \\
\hline 12 & 46 & 38 & 42 & 102 & 46 & 50 & 48 & 192 & 44 & 42 & 50 \\
\hline 13 & 50 & 45 & 50 & 103 & 50 & 50 & 50 & 193 & 35 & 50 & 42 \\
\hline 14 & 44 & 44 & 50 & 104 & 44 & 48 & 44 & 194 & 47 & 48 & 42 \\
\hline 15 & 42 & 48 & 42 & 105 & 35 & 50 & 46 & 195 & 38 & 50 & 50 \\
\hline 16 & 47 & 50 & 38 & 106 & 44 & 50 & 50 & 196 & 42 & 38 & 44 \\
\hline 17 & 38 & 50 & 36 & 107 & 39 & 45 & 42 & 197 & 42 & 45 & 38 \\
\hline 18 & 40 & 42 & 40 & 108 & 47 & 34 & 42 & 198 & 50 & 44 & 48 \\
\hline 19 & 50 & 50 & 48 & 109 & 38 & 42 & 50 & 199 & 46 & 48 & 50 \\
\hline 20 & 42 & 48 & 38 & 110 & 40 & 50 & 50 & 200 & 48 & 42 & 44 \\
\hline 21 & 44 & 50 & 38 & 111 & 50 & 34 & 48 & 201 & 44 & 50 & 46 \\
\hline 22 & 35 & 38 & 42 & 112 & 42 & 47 & 50 & 202 & 35 & 38 & 40 \\
\hline 23 & 47 & 45 & 50 & 113 & 50 & 45 & 44 & 203 & 47 & 48 & 42 \\
\hline 24 & 38 & 34 & 38 & 114 & 46 & 44 & 46 & 204 & 38 & 50 & 42 \\
\hline 25 & 50 & 42 & 46 & 115 & 50 & 48 & 50 & 205 & 40 & 50 & 50 \\
\hline 26 & 42 & 44 & 42 & 116 & 44 & 50 & 42 & 206 & 47 & 44 & 50 \\
\hline 27 & 50 & 45 & 42 & 117 & 35 & 38 & 36 & 207 & 38 & 48 & 42 \\
\hline 28 & 46 & 42 & 42 & 118 & 40 & 42 & 50 & 208 & 40 & 50 & 42 \\
\hline 29 & 50 & 42 & 50 & 119 & 50 & 50 & 50 & 209 & 50 & 50 & 50 \\
\hline 30 & 44 & 50 & 50 & 120 & 42 & 38 & 42 & 210 & 42 & 42 & 50 \\
\hline 31 & 35 & 34 & 38 & 121 & 50 & 50 & 38 & 211 & 50 & 50 & 48 \\
\hline 32 & 47 & 38 & 48 & 122 & 46 & 50 & 36 & 212 & 46 & 48 & 50 \\
\hline 33 & 38 & 45 & 45 & 123 & 50 & 45 & 35 & 213 & 50 & 50 & 44 \\
\hline 34 & 40 & 44 & 44 & 124 & 50 & 42 & 46 & 214 & 44 & 38 & 46 \\
\hline 35 & 47 & 48 & 46 & 125 & 42 & 38 & 50 & 215 & 35 & 45 & 50 \\
\hline 36 & 38 & 50 & 50 & 126 & 50 & 38 & 42 & 216 & 40 & 44 & 42 \\
\hline 37 & 40 & 44 & 42 & 127 & 46 & 45 & 42 & 217 & 50 & 48 & 42 \\
\hline 38 & 40 & 42 & 42 & 128 & 50 & 44 & 50 & 218 & 42 & 50 & 50 \\
\hline 39 & 42 & 50 & 50 & 129 & 44 & 48 & 50 & 219 & 50 & 50 & 50 \\
\hline 40 & 44 & 48 & 50 & 130 & 35 & 42 & 38 & 220 & 46 & 50 & 42 \\
\hline 41 & 42 & 44 & 42 & 131 & 40 & 50 & 48 & 221 & 50 & 42 & 38 \\
\hline 42 & 47 & 40 & 38 & 132 & 50 & 42 & 48 & 222 & 44 & 48 & 36 \\
\hline 43 & 38 & 50 & 36 & 133 & 42 & 50 & 48 & 223 & 50 & 48 & 35 \\
\hline 44 & 50 & 50 & 35 & 134 & 50 & 48 & 50 & 224 & 42 & 50 & 46 \\
\hline 45 & 42 & 42 & 48 & 135 & 46 & 50 & 44 & 225 & 50 & 44 & 50 \\
\hline 46 & 50 & 50 & 42 & 136 & 50 & 44 & 46 & 226 & 46 & 48 & 42 \\
\hline 47 & 46 & 48 & 38 & 137 & 35 & 38 & 34 & 227 & 44 & 48 & 42 \\
\hline 48 & 50 & 50 & 48 & 138 & 44 & 46 & 42 & 228 & 44 & 50 & 50 \\
\hline 49 & 44 & 50 & 50 & 139 & 44 & 50 & 42 & 229 & 35 & 50 & 50 \\
\hline 50 & 40 & 45 & 44 & 140 & 40 & 50 & 50 & 230 & 47 & 48 & 42 \\
\hline 51 & 47 & 44 & 48 & 141 & 50 & 48 & 50 & 231 & 38 & 50 & 42 \\
\hline 52 & 38 & 42 & 50 & 142 & 42 & 50 & 48 & 232 & 40 & 44 & 44 \\
\hline 53 & 40 & 50 & 44 & 143 & 50 & 50 & 50 & 233 & 35 & 45 & 50 \\
\hline 54 & 47 & 45 & 46 & 144 & 46 & 48 & 44 & 234 & 47 & 46 & 48 \\
\hline 55 & 38 & 34 & 50 & 145 & 50 & 50 & 48 & 235 & 38 & 42 & 50 \\
\hline 56 & 40 & 42 & 42 & 146 & 44 & 44 & 50 & 236 & 50 & 50 & 44 \\
\hline
\end{tabular}




\begin{tabular}{|c|c|c|c|c|c|c|c|c|c|c|c|}
\hline 57 & 50 & 50 & 48 & 147 & 50 & 48 & 42 & 237 & 42 & 44 & 46 \\
\hline 58 & 42 & 34 & 50 & 148 & 47 & 50 & 42 & 238 & 50 & 38 & 50 \\
\hline 59 & 44 & 38 & 50 & 149 & 38 & 50 & 50 & 239 & 46 & 45 & 42 \\
\hline 60 & 50 & 45 & 38 & 150 & 40 & 42 & 38 & 240 & 50 & 44 & 42 \\
\hline 61 & 46 & 44 & 48 & 151 & 50 & 48 & 42 & 241 & 44 & 48 & 50 \\
\hline 62 & 50 & 48 & 50 & 152 & 42 & 50 & 38 & 242 & 35 & 36 & 35 \\
\hline 63 & 44 & 50 & 44 & 153 & 40 & 50 & 50 & 243 & 47 & 50 & 46 \\
\hline 64 & 44 & 50 & 46 & 154 & 50 & 45 & 42 & 244 & 44 & 50 & 50 \\
\hline 65 & 47 & 50 & 35 & 155 & 42 & 42 & 46 & 245 & 40 & 50 & 42 \\
\hline 66 & 38 & 48 & 48 & 156 & 42 & 42 & 36 & 246 & 47 & 44 & 42 \\
\hline 67 & 40 & 43 & 38 & 157 & 44 & 50 & 35 & 247 & 48 & 48 & 50 \\
\hline 68 & 50 & 50 & 38 & 158 & 50 & 34 & 46 & 248 & 40 & 50 & 50 \\
\hline 69 & 42 & 45 & 48 & 159 & 46 & 38 & 50 & 249 & 50 & 50 & 38 \\
\hline 70 & 50 & 46 & 50 & 160 & 50 & 45 & 42 & 250 & 42 & 42 & 48 \\
\hline 71 & 46 & 42 & 44 & 161 & 44 & 44 & 42 & 251 & 50 & 50 & 38 \\
\hline 72 & 50 & 50 & 48 & 162 & 35 & 48 & 50 & 252 & 46 & 48 & 48 \\
\hline 73 & 44 & 34 & 50 & 163 & 47 & 50 & 50 & 253 & 50 & 50 & 50 \\
\hline 74 & 35 & 38 & 44 & 164 & 38 & 50 & 38 & 254 & 44 & 38 & 44 \\
\hline 75 & 40 & 45 & 46 & 165 & 40 & 42 & 48 & 255 & 45 & 45 & 46 \\
\hline 76 & 50 & 44 & 50 & 166 & 50 & 50 & 38 & 256 & 40 & 44 & 48 \\
\hline 77 & 42 & 48 & 42 & 167 & 42 & 48 & 48 & 257 & 50 & 48 & 38 \\
\hline 78 & 50 & 50 & 42 & 168 & 50 & 50 & 50 & 258 & 42 & 50 & 38 \\
\hline 79 & 46 & 50 & 50 & 169 & 46 & 38 & 44 & 259 & 50 & 50 & 48 \\
\hline 80 & 50 & 42 & 50 & 170 & 50 & 45 & 46 & 260 & 46 & 50 & 50 \\
\hline 81 & 44 & 44 & 38 & 171 & 44 & 44 & 46 & 261 & 50 & 42 & 44 \\
\hline 82 & 35 & 48 & 48 & 172 & 35 & 48 & 50 & 262 & 44 & 50 & 46 \\
\hline 83 & 47 & 50 & 50 & 173 & 40 & 50 & 42 & 263 & 50 & 48 & 50 \\
\hline 84 & 44 & 50 & 44 & 174 & 38 & 44 & 42 & 264 & 42 & 50 & 48 \\
\hline 85 & 40 & 45 & 46 & 175 & 42 & 50 & 50 & 265 & 50 & 44 & 42 \\
\hline 86 & 50 & 42 & 50 & 176 & 50 & 48 & 50 & 266 & 46 & 48 & 50 \\
\hline 87 & 42 & 50 & 42 & 177 & 46 & 50 & 42 & 267 & 50 & 50 & 50 \\
\hline 88 & 43 & 40 & 42 & 178 & 42 & 42 & 38 & 268 & 48 & 50 & 48 \\
\hline 89 & 46 & 38 & 50 & 179 & 44 & 45 & 50 & & & & \\
\hline 90 & 42 & 45 & 44 & 180 & 50 & 46 & 42 & & & & \\
\hline
\end{tabular}

Data Source: Filled Questionnaire, processed.

\subsection{Data Analysis}

\subsubsection{Testing Research Instruments}

The feasibility of the questionnaire as a data retrieval tool is tested based on the score of its validity and reliability. Validity test of using the product moment correlation Among indicator scores $\left(\mathrm{X}_{1}, \mathrm{X}_{2}\right)$ with a total score of indicator (Y) obtained the result that the entire item per tanyaan the variable has a greater correlation coefficient of $r_{\text {table }}=$ 0.207 and significance of less than 0.05 . While test reliability by Cronbach's alpha values result that all variable value is greater than the minimum threshold value that is equal to 0.300 . Thus it can be concluded that all items of questions in the questionnaire is valid and reliable so that it can be used in research.

\subsubsection{Classic Assumption Test}

Table 2. Classic assumption test results

\begin{tabular}{llll}
\hline Testing Criteria & \multicolumn{1}{c}{ Method } & \multicolumn{1}{c}{ Results } & Information \\
\hline Normality & $\begin{array}{l}\text { Normal Graph PP Plot of } \\
\text { Regression Standardized Residual }\end{array}$ & $\begin{array}{l}\text { The distribution of data of all variables } \\
\text { approaching the normal line (not } \\
\text { experiencing skewness) }\end{array}$ & Distributed normally. \\
\hline Multicollineraity & VIF (Variance Inflation Factor) & $\begin{array}{l}\text { All independent variables have VIF } \\
\text { value <10 with tolerance limit }>0.1\end{array}$ & There is no multicollinearity \\
\hline Autocorrelation & Durbin Watson (DW) & N worth 1.815 points & It does not attempt autocorrelation \\
\hline Heteroscedasticity & Spearment Level Correlation & $\begin{array}{l}\text { N use values sig (2-tailed) for the three } \\
\text { variables more> alpha (0.05) }\end{array}$ & $\begin{array}{l}\text { It does not attempt occurred } \\
\text { heterocedasticity }\end{array}$ \\
\hline
\end{tabular}




\subsubsection{Multiple Linear Regression Analysis}

Table 3. Results of multiple linear regression testing

\begin{tabular}{lcccc}
\hline Criteria / Variables & Coefficient & t & Sig & Information \\
\hline Canstant & \multicolumn{3}{c}{36348} \\
\hline Organizational Learning & .139 & 2,273 & .024 & Partially affected \\
Locus of Control & .051 & .830 & .407 & No partial effect \\
F & 3.271 & & .040 & Influential simultaneously \\
\hline R Square & \multicolumn{3}{l}{} & \\
\hline
\end{tabular}

Source: SPSS output, processed.

Some things can be concluded based on Table 3, namely:

a. Coefficient of correlation $\mathrm{R}=0,024$ indicate that the influence of variables $\mathrm{X}_{1}, \mathrm{X}_{2}$ to $\mathrm{Y}$ is at $24 \%$ and the rest (66\%) influenced by other variables not examined.

b. Coefficient of constant $=36348$, this means that if the value of all independent variables equal to zero, then the competence of employees will be valued at 36.348 points.

c. Coefficient of $X_{1}=0.139$ suggesting that if all other variables constant, and if the value of the variable Organizational Learning increased by one point, then competence will increase by 0.139 points.

d. Coefficient of $\mathrm{X}_{2}=0,052$ this shows that if all other variables constant, and if the value of the variable Locus of Control increased by one point, then competence will increase by 0.052 points.

e. Testing hypotheses:

- Organizational Learning has a $\mathrm{t}_{\text {count }}$ of $2.273(\mathrm{Sig}=\mathrm{t}=0.024<0.05)$, then the partial variable has an effect on Employee Competency variable.

- Locus of Control has a $t_{\text {count }}$ of 0,830 (Sig $t=0.407 \geq 0.05$ ), then the partial variable does not affect the Employee Competency variable.

- Both variables of organizational learning and locus of control simultaneously affect the competence of employees.

\section{Discussion}

The preliminary study of this study discusses the effect of participative budgeting on managerial performance through employee commitment and innovation perception as a moderating variable in order to improve performance accountability. The study proves that budgetary participation has an effect on managerial performance. Organizational commitment is able to moderate that influence, while perceptions of innovation cannot moderate. Therefore action is needed to ensure that employees' commitment can be improved so that performance accountability can be realized. This research concludes that to maximize employee commitment, organizational learning process must be implemented well. Performance accountability will be achieved if employees are able to report accountable use of the budget and have a high commitment to advance the organization.

The design of budget accountability that has been collected by researchers to improve accountability reporting are: 


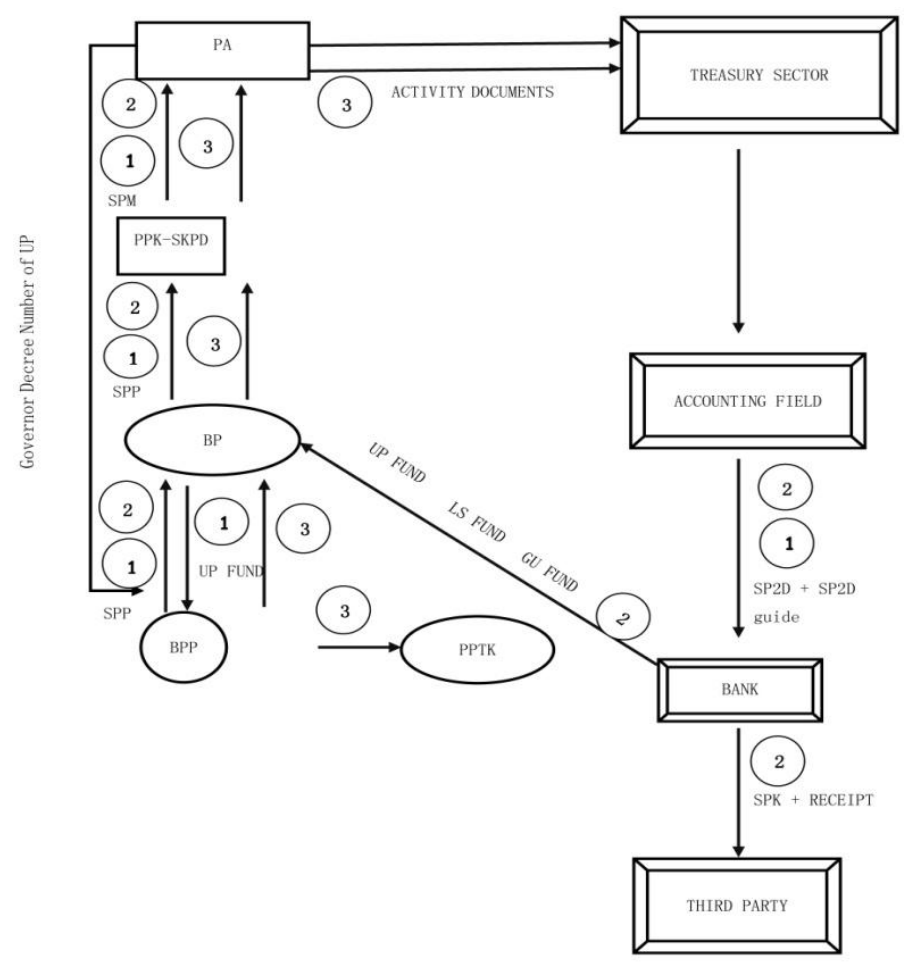

Figure 1. Flowchart budget accountability

Figure 1 on Flowchart Budget Accountability is explained about Budget Procedure Procedures, Budget Withdrawal Procedures, Budget Implementation Procedures and Budget Disbursement Flowcharts. Within the Flowchart there are several Government Areas involved, starting from Budget Users or more commonly referred to as Head of Service, PPK-SKPD (Finance Administration Officials-SKPD) or Secretary of Head of Service, BP (Expenditure Treasurer) or BPP (Spending Treasurer) which is in charge of preparing the budget documents that are useful in the process of Budgeting to Disbursement of Budget. In the process of preparing the documents of the Spending Treasurer and / or the Spending Assistant Treasurer is assisted by the PPTK (Activity Technical Activity Officer). There is also the Field of Treasury and Accounting Sector. The governor is also involved in the budget accountability process.

While the Budget Reporting Flowchart is presented in Figure 2:

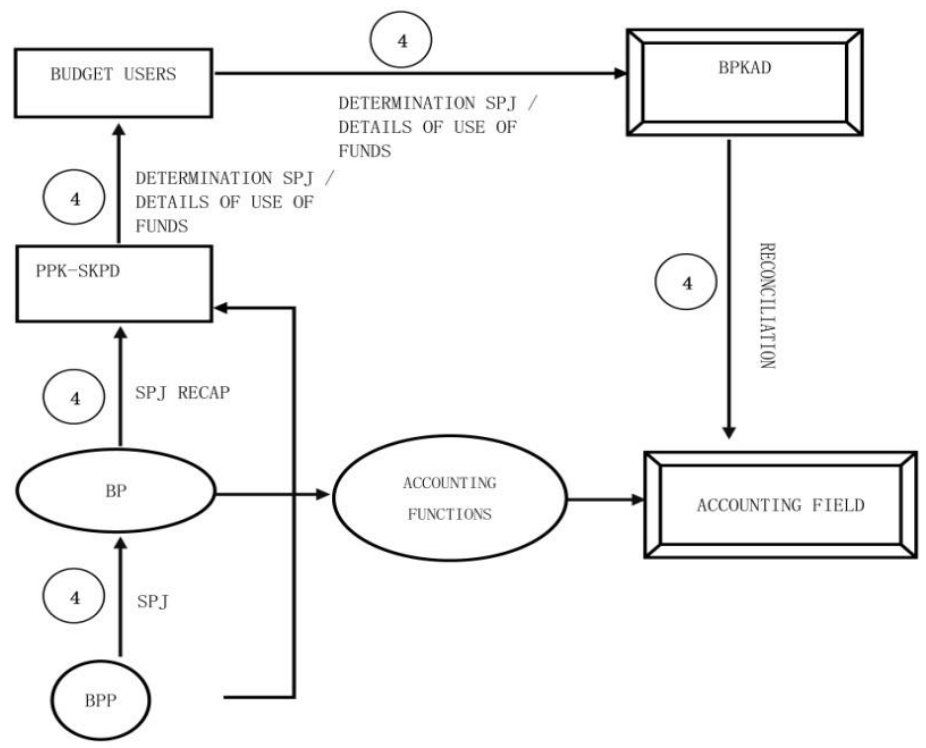

Figure 2. Flowchart budget reporting 
Figure 2 shows the Flowchart Budget Reporting there are several processes or plots, including:

a. Number 1 (one) is a plot of the Budget Procedure Procedure and several supporting documents, from the receipt of the Decision Letter from the Governor for the disbursement of UP funds. The Spending Treasurer and / or the Spending Treasurer shall make the SPP (Payment Request Letter) after the completion of submission to the PPP-SKPD (Financial Administration Officials-SKPD) to be issued SPM (Payment Order) and verified by the Budget User. Then the SPM is sent to the Regional Treasury for the issuance of SP2D (Fund Disbursement Order).

b. Number 2 (two) is the flow of the Budget Disbursement Procedure and several supporting documents. The initial step is equal to the budgeting that is made by SPP by the Spending Treasurer and / or the Spending Treasurer then issued SPM by PPK-SKPD and verified Budget User then sent to Regional Treasury for SP2D. All these steps apply to disbursement of UP Funds, LS Funds, or GU Funds. Fund disbursement UP, after SP2D issued and Introduction SP2D entered into Bank owned Balitbang then the money is immediately disbursed and entered into the Spending Treasurer. The disbursement of the LS Fund is also the same as the disbursement of the UP Fund, only the LS Fund here refers to two types of disbursement, the first after SP2D and SP2D Introduction to the Balitbang Bank, the Fund can be disbursed directly into the Spending Treasurer, used for Employee Expenditure. For Procurement of Goods and Services after SP2D and SP2D Introduction, the funds will be entered into Bank from a third party, it happens if there has been an agreement with third party. From Balitbang itself if the Third Party agrees with the agreement it will be equipped SPK (Work Order) and Receipt and then made the report of the examination. Disbursement of GU Funds is similar to disbursement of UP and LS Funds, after SP2D is issued and SP2D Introduction goes to Balitbang's Bank, the GU Fund can be disbursed directly into the Spending and Spending Bonds. GU funds are disbursed after activities.

c. Number 3 (three) is a flow of Budget Implementation Procedures and several supporting documents, fund UP in Breakdown into activities conducted by Balitbang. The Deployment and / or Asset Management Treasurer assisted by the Technical Activity Officer (PPTK) shall draw up the activities for a period of one year and in accordance with the Funds obtained, then the documents shall be verified by the Budget User through PPK-SKPD. Then sent to the Regional Treasury for checking again.

d. Number 4 (four) is the flow of the Budget Reporting Procedure and several supporting documents, the Spending Treasurer and / or the Spending Assistant make an SPJ (Letter of Responsibility) about the details of the use of funds and then recapitulated by PPK-SKPD and authorized by the Budget User. After it is declared complete the SPJ document is sent to BPKAD (Regional Financial Management and Assets Agency) and checked directly by Regional Accounting Sector. Besides, the Spending Treasurer also performs accounting functions where there are documents of SPJ files that are sent directly to the Regional Accounting Division to be performed Reconciliation / matching with the SPJ sent through BPKAD.

\section{Conclusion}

The main conclusions of the study are:

1) Budgetary participation directly affects managerial performance.

2) Organizational commitment is able to moderate the influence of budgetary participation on managerial performance.

3) Perceptions of innovation can not moderate the effect of budgetary participation on managerial performance.

4) Learning organization has an effect on employee commitment, while the locus of control has no effect.

5) Accountability performance achieved if the employee has a firm commitment to promote the organization that can be realized through a learning process and are able to report a budget organization accountable.

\section{References}

Agusti, R. (2012). Effect of Budgetary Participation on Local Government Reform Performance with Variable Moderated by Decentralization and Cultural Organization. Economic Journal, 20(3), 1-15.

Bronell, P., \& McInnes, M. (1986). The budgetary Participation, motivation, and managerial performance. The Accounting Review, 61(4).

Dill, D. D. (1999). Academic Accountability and University Adaptation: The Architecture of an Academic Learning Organization. Higher Education, 38, 127. https://doi.org/10.1023/A:1003762420723

Dixon, N. M. (1997). The Hallways of Learning, American Management Association. Organizational Dynamics, 
25(4), 23. https://doi.org/10.1016/S0090-2616(97)90034-6

Fiol, C. M., \& Lyles, M. A. (1985). Organizational Learning. Academy ofManagement Review, 10(4), 803.

Frucot, V., \& Stephen, W. (2006). Managerial levels and the effects of bud getary participationon manajers. Managerial Auditing Journal, 21(2), 191-206. https://doi.org/10.1108/02686900610639310

Ghazhali, I., \& Fahrianta, R. Y. (2002). Indirect Influence on Managerial Performance Budgeting System: Motivation as an intervening variable. Journal of Accounting Research, Economic Management, 2(1).

Jogiyanto, H. M., \& Willy, A. (2014). Concepts and Applications PLS (Partial Least Square) for Empirical Research. BPFE, Yogyakarta

Kuwaviyah, M. S. (2010). The Role of Organizational Commitment and Innovation Variables on Relations between Budgeting and Performance: A Case Study on SKPD Magelang. Journal of Accounting and Auditing, 7(1), 33-48.

Mard, I. (2002). Public Sector Accounting. Yogyakarta: ANDI -Ofset.

Mowen, M., \& Hansen, D. R. (2004). Management Accounting (7th ed.). Jakarta: Salemba Four.

Munandar, M. (2001). Budgeting: Planning Coordination of Supervision Work. Yogyakarta: Yogyakarta BPFE.

Ompusunggu, K. B., \& Bawono, I. R. (2007). Effect of Budget Participation and Job Relevant Information (JRI) against Asymmetric Information. Journal of Accounting and Public Sector Finance, 8(1).

Riyadi, S. (2000). Motivation and Delegation of Authority as moderating variables in the Relationship Between the Budget Participation and Managerial Performance. Indonesian Journal of Accounting Research, 2(2).

Robbins, S. P. (2003). Organizational Behavior (10th ed.). New Jew Jersey: Prentice Hall.

Robert, K., \& Angelo, K. (2005). Organizational Behavior. Salemba Four, Jakarta.

Sardjito, B. (2005). Participation Budget and Performance Manager. Journal of Economics and Business, 6(1).

Sharon, A. S. (2013). Effectiveness and Efficiency Analysis Executing Budget Planning Agency (Bappeda) South Minahasa. Journal EMBA, 1, 74-81.

Stoner, J. A. F., Edward, F. R., \& Daniel, R. G. Jr. (1995). Management (6th ed.). New Jersey: Prentice Hall.

Subramaniam, N., \& Ashkanasy, N. M. (2001). The effect of organizational culture perceptions between budgetary participation and managerial job-related outcomes. Australian Journal of Management, 26(1), 35-55. https://doi.org/10.1177/031289620102600103

Sumarno, J. (2005). Effect of Organizational Commitment and Leadership Style on the Relationship between Participation Budget and Performance Managerial. Journal of Business Strategy, 14(2).

Supranto, J. (2000). Statistical Theory and Applications. Jakarta: Erlangg.

Supriyono, R. A. (2005). Effects of Organizational Commitment, Desire Social and Information Asymmetry on the Relationship Between Participation Peng budget by Performance Manager. Indonesian Journal of Economics and Business, 20(1).

\section{Copyrights}

Copyright for this article is retained by the author(s), with first publication rights granted to the journal.

This is an open-access article distributed under the terms and conditions of the Creative Commons Attribution license (http://creativecommons.org/licenses/by/4.0/). 